\section{Lawyer up}

G reat Eastern University did not have a lawyer as a voting member of its IACUC but Joseph Kleiner, an attorney on the school's legal staff, attended all IACUC meetings as a non-voting observer. Additionally, when an IACUC hearing about protocol noncompliance or animal mistreatment occurred, Kleiner attended to help assure that any action taken by the committee was compliant with school policy and federal regulations.

When it was alleged that Dr. Louis Macdonald started a research project without IACUC approval, Macdonald was asked to meet with a subcommittee of the IACUC to explain his actions. Before the meeting occurred, Macdonald made it clear to the IACUC chairman that he was very annoyed with the allegation and the need for a meeting because he only added a few mice to an already approved protocol. Nevertheless, a meeting was scheduled and when Macdonald entered the meeting room and was introduced to attorney Kleiner, he wanted to know why a lawyer had to be present because he felt intimidated without having a lawyer of his own being there. The IACUC chairman explained that Kleiner was there to assure that Macdonald's rights were being protected and certainly not to intimidate him. But Macdonald contended that Kleiner was employed by the school's administration to represent and protect the school, not him, and he wanted to have his own lawyer present before any further discussion occurred. The chairman said that was not the policy of the school or the IACUC, that there had not been any complaints in past cases about Kleiner being there, and it was important for the meeting to progress.

What do you think? Should Dr. Macdonald be allowed to have his own legal representation as a matter of due process, or can Kleiner adequately represent both the school and Macdonald?

\section{Jerald Silverman}

University of Massachusetts Medical School, Worcester, Massachusetts, USA. e-mail: Jerald.Silverman@umassmed.edu

\title{
Delivery of an Upjohn Warning and right to due process
}

T he general counsel for Great Eastern University solely represents the interests of the institution, and not the employees. Attorney Kleiner can only represent the university to ensure school policies are followed and the university is in compliance with applicable laws and regulations. Attorney Kleiner should specifically state to Dr. Macdonald that he serves as counsel for Great Eastern University, does not represent Dr. Macdonald, and cannot offer Dr. Macdonald legal advice. This verbal statement by Attorney Kleiner is required and should also be documented in the minutes of the general IACUC meetings and its subcommittee meetings. This purpose and intent is most commonly referred to as an "Upjohn Warning", and is the notice an attorney provides to an employee to inform him/her that the attorney represents the institution and not the individual employee ${ }^{1}$. While the intent of an Upjohn Warning is to establish the legal representation of the counsel present and to protect the attorney-client privilege of the institution, use of this warning is just as applicable and should be integrated into the internal investigation processes of a robust compliance program.

In the course of an investigation into an allegation of noncompliance, the IACUC has the responsibility to assure the investigation is conducted in a fair and unbiased manner and that the respondent to the allegation is offered due process and fair notice. The right to due process includes providing the respondent, Dr. Macdonald: notification of the allegation levied against the respondent; the opportunity to review the details of the allegation and evidence collected by the subcommittee; the opportunity to challenge the evidence collected, provide an alternative interpretation of the evidence, and put forward additional evidence; the right to assistance from personal legal counsel or another adviser, if so desired; and access to a mechanism for appeal ${ }^{2}$.

Great Eastern's IACUC should have a policy and a detailed SOP for the consideration of noncompliance allegations and the conduct of an investigation into such allegations. The IACUC subcommittee should inform the investigator of the capacities and roles of the individuals present and the intent of the meeting with him. A thorough explanation of the purposes and processes for the subcommittee's investigation and full transparency of these processes might ease Dr. Macdonald's discomfort and desire for personal legal counsel. Ultimately, however, he should not be denied due process. Incorporation of process details will also alleviate any confusion about the roles of individuals present during the investigation on behalf of the IACUC Chair.

\section{Laura Conour \\ Princeton University, Princeton, New Jersey, USA. e-mail:lconour@princeton.edu}

Published online: 24 July 2018

https://doi.org/10.1038/s41684-018-0109-5

\footnotetext{
References

1. Thomson Reuters Practical Law. Glossary: Upjohn Warning. https://content.next.westlaw.com/Document/ Ibb0a39dfef0511e28578f7ccc38dcbee/View/FullText. $\mathrm{html}$ ? contextData $=($ sc.Default $) \&$ transitionType $=$ Default\&firstPage $=$ true\&bhcp $=1$

2. Hansen, B. et al. Ensuring due process in the IACUC and animal welfare setting: considerations in developing noncompliance policies and procedures for institutional animal care and use committees and institutional officials. FASEB J 10 $4216-4225$ (2017).
} 